\title{
A comparative study of practicing cross-infection control of dental prostheses and implant components among prosthodontists and dental technicians in Qassim province, Saudi Arabia
}

\author{
Nabila A Sedky \\ Community and Preventive Dentistry, College of Dentistry, Qassim University, Saudi Arabia \\ doi: 10.3396/ijic.v15i4.016.19
}

\begin{abstract}
The objectives were to compare the performance of infection control practices among prosthodontists and dental technicians in Al-Qassim Province, Kingdom of Saudi Arabia with regard to dental prostheses, impression copings, implant analogs and customized implant abutments (implant components). Self-administered questionnaires were submitted to 48 prosthodontists and 46 laboratory technicians in three cities. The questionnaires consisted of 19 questions for prosthodontists and 21 questions for laboratory technicians. All questionnaires were reviewed in situ to make sure they were fulfilled completely.
\end{abstract}

Astatistically significant difference was found between participants regarding receiving refresher infection control courses, while there was no statistical difference concerning disinfection protocols as well as communication regarding disinfection of prosthesis. For disinfection of different types of prosthesis before sending to lab/clinic, higher percentage of dentists applied this procedure $(42.55 \%$ and $40.43 \%)$ compared to technicians (17.02\% and $18.09 \%$ ), while disinfection after return was higher among technicians (43.62\% and $46.81 \%)$. Concerning implant components, dentists registered a low percentage for disinfection/sterilization of sent and returned items (13.83\% and $7.45 \%)$, whereas $46.81 \%$ of technicians disinfect/sterilize implant components upon return from clinic.

In conclusion, there was shortage of appropriate practice of infection control procedures in prosthodontic clinics and labs regarding the disinfection of dental prostheses as well as the disinfection/sterilization of implant components upon sent/returned to the dental lab/clinic.

Keywords: infection control, dentistry, dental laboratories, dental prosthesis, Saudi Arabia

\section{Corresponding Author}

Nabila A Sedky

Community and Preventive Dentistry, College of Dentistry, Qassim University, Buraidah, Saudi Arabia

E-mail: prof.nabila.sedky@qudent.org; nasedky@yahoo.com 


\section{Introduction}

There is growing worry concerning cross-infection issue in dental clinics and laboratories, particularly after discovering that transmission of infection to dental technicians is chiefly through contaminated impressions and also via inappropriate management of clinical items received in the dental laboratory. ${ }^{1}$

The human oral cavity is a rich environment for several infectious and harmful microorganisms to be transmitted, inoculated, and grow through blood and saliva, which are the common means for spread of these microbial agents in the dental clinic as well as the dental laboratory. ${ }^{2-4}$ On a daily basis, dentists and dental laboratory technicians are exposed to a wide variety of microorganisms that can produce infectious diseases. Findings of a previous study revealed that out of ten sterile complete dentures that were fractured and delivered to various dental laboratories for repair, nine were contaminated with potentially pathogenic microorganisms. ${ }^{5}$

Dental impressions, bite registration, trial dentures and final prostheses are prone to contamination in the patient's mouth which can promote the spread of infectious agents to the clinician, patients as well as to the dental technicians. ${ }^{6-8}$ The Centers for Disease Control and Prevention (CDC) and World Health Organization (WHO) recommend cleaning and disinfection of all patients' prostheses prior to delivery to the dental lab and upon return to the dental clinic. 9,10 In a survey conducted by Hatzikyriakos et al., ${ }^{11} 26 \%$ of laboratories did not disinfect the impressions, while $56 \%$ of participants reported that they have no training about infection control in laboratories. These outcomes denote that infection control programs should be developed and implemented by dental technicians prior to handling any clinical items from dental clinics. ${ }^{1}$

Although rinsing under running water was the recommended procedure for cleaning impressions, ${ }^{12}$ that proved to reduce about $90 \%$ of the count of microorganisms on their surfaces. However, a measurable bacterial load still remains on impressions that can be transferred to casts. ${ }^{13,14}$ Casts poured from impressions can also hide infectious microorganisms that can spread in the laboratory during trimming the casts. ${ }^{15}$ Casts can be disinfected by immersing or spraying them with disinfecting solutions ${ }^{16-21}$ and also by adding chemical disinfectants directly to the dental stone. ${ }^{17,22}$

Bacterial species lodging in the internal surfaces of the implant analogs and customized implant abutments as well as the impression copings are not surprising. ${ }^{23}$ According to the guidelines of the American Dental Association (ADA) these items are classified as semi-critical medical devices ${ }^{21}$ that should be sterilized after each use if they are heat tolerant. ${ }^{21}$ The European Union (EU) demands that medical devices, including implant components and impression copings, be resterilizable and be sterilized as recommended by the manufacturer; ${ }^{24}$ thus, decontamination/sterilization recommendations for surgical instruments should be employed. ${ }^{25}$ For heat-sensitive abutments including ceramic, resin, or resin composite veneered abutments, ${ }^{26-29}$ high-level disinfection would be appropriate.

Appropriate performance of cleaning, disinfection and sterilization procedures both in the dental office and the laboratory will be ensured through effective communication and organization between them, so as to guarantee these procedures, where all aspects of dental activities should be covered by infection control practices, however duplication should be avoided. ${ }^{30}$

Previously, many studies have been conducted on infection control in dental clinics and also in dental laboratories., ${ }^{3,4,71-34}$ Yet, these studies did not cover some of the important infection control procedures in prosthodontic clinics and some crucial items in the dental lab. Based on these considerations, the aim of this study was to compare the performance of infection control practices among prosthodontists and dental technicians in Al-Qassim Province, Saudi Arabia with regard to dental prostheses, impression copings, implant analogs and customized implant abutments (implant components). The information obtained from this study will assist in the development of infection control guidelines to be implemented in dental laboratories and prosthodontic clinics on a large scale in the field of dentistry. 


\section{Material and Methods}

The current cross-sectional study constituted anonymous pre-tested self-administered questionnaires that were formulated and submitted to 48 prosthodontists and 46 laboratory technicians randomly selected from those employed with the Ministry of Health $(\mathrm{MoH})$, in three cities from AlQassim Province (Buraidah, Unaizah, and Arrass). According to the annual statistical book of $\mathrm{MoH} 2017$, the total number of dentists and dental technicians appointed by $\mathrm{MoH}$ was 3991 dentists and 3153 dental technicians. ${ }^{35}$

All questionnaires were applied by only one operator, who was always present during filling out the forms, to avoid variations on the data-base collection. The questionnaires consisted of 18 questions for prosthodontists and 20 questions for laboratory technicians which aimed to gather information about the intended subjects. The questions were directed to each of the dentists in the dental clinic and for the dental technicians in the dental laboratory. All questionnaires were reviewed in situ to make sure they were fulfilled completely.

The English version of the questionnaires was translated into Arabic language and filled by the investigator then pre-tested on randomly selected 6 dentists and dental technicians to ensure its comprehension, practicability, validity, interpretation of responses, and reliability (Cronbach's a for dentists and dental technicians $=0.813$ and 0.861 , respectively).

\section{Ethical considerations}

Ethical approval was obtained from the Ethics Committee of the Dental Research Centre of Qassim University (Code \#: EA/5/2018). Data were collected after written consent from each participant with a brief description about the importance of the study.

\section{Statistical Analysis}

Statistical analysis was conducted using the SPSS program (IBM Corp. Released 2015. IBM SPSS Statistics for Windows, Version 23.0. Armonk, NY: IBM Corp.). All statistical analyses were carried out at a significance level less than 0.05 and 0.001 . Results were analyzed and compared by means of cross- tabulation and statistical association tests. The chisquare test was used to test associations between the studied groups and the different investigated variables. Finally, regression analysis was conducted to figure out which factors that have the main effect on the studied condition.

\section{Results}

Forty-eight prosthodontists and forty-six dental technicians completely filled the submitted questionnaires with mean age of 38.67 (SD +10.65 ) years for dentists and 37.39 (SD +9.06) years for dental technicians.

On enquiry about whether the participating subjects had undergone any refresher courses on infection control for the past year, $41.49 \%$ of the dentists and $26.60 \%$ of the dental technicians reported they had, with a statistically significant difference between them. Additionally, a statistically significant difference was found between the contributors concerning the products commonly used for disinfection. On the other hand, there was no statistically significant difference with regard to having a written infection control policy for incoming prostheses, as well as for any communication regarding the disinfection of prostheses sent/received to/in the laboratory (Table I).

Table II shows results relating to disinfection of prostheses and implant components BEFORE sending to the lab/clinic. The majority of dentists (42.55\%) disinfect the metal try in, porcelain and ceramic crowns and bridges in their clinics, compared to only $17.02 \%$ of the dental technicians $(p<0.001)$. Statistically significant differences were identified related to how this procedure is performed. Differences were also identified related to the disinfection of bite registration, trial dentures and complete dentures, and the details of how these procedures were performed (Table II). On the other hand, no statistically significant difference was identified when asking about disinfection/sterilization of the impression copings, implant analogs and customized implant abutments, where most of the prosthodontists and technicians replied that they didn't perform this issue, though a statistically significant difference was observed related to the methods used (Table II). 
Table I. Infection control system in dental office and prosthodontic lab

\begin{tabular}{|c|c|c|c|c|c|}
\hline \multirow[b]{2}{*}{ Variable } & & \multicolumn{2}{|c|}{ Group } & \multirow[b]{2}{*}{ Total } & \multirow[b]{2}{*}{$\begin{array}{l}\chi^{2} \\
(\mathrm{P})\end{array}$} \\
\hline & & Dentists & $\begin{array}{r}\text { Dental } \\
\text { Technicians }\end{array}$ & & \\
\hline \multirow{2}{*}{$\begin{array}{l}\text { Refresher courses on } \\
\text { infection control for the past } \\
\text { year }\end{array}$} & Yes & $41.49 \%$ & $26.60 \%$ & $68.09 \%$ & \multirow{3}{*}{$\begin{array}{r}7.823^{* *} \\
(0.005)\end{array}$} \\
\hline & No & $9.6 \%$ & $22.34 \%$ & $31.91 \%$ & \\
\hline Total & & $51.06 \%$ & $48.94 \%$ & $100.0 \%$ & \\
\hline \multirow{2}{*}{$\begin{array}{l}\text { Written infection control } \\
\text { policy [disinfection protocol] } \\
\text { for incoming prosthesis }\end{array}$} & Yes & $42.55 \%$ & $37.23 \%$ & $79.79 \%$ & \multirow{3}{*}{$\begin{array}{r}0.765 \\
(0.269)\end{array}$} \\
\hline & No & $8.51 \%$ & $11.70 \%$ & $20.21 \%$ & \\
\hline Total & & $51.06 \%$ & $48.94 \%$ & $100.0 \%$ & \\
\hline \multirow{2}{*}{$\begin{array}{l}\text { Communication regarding } \\
\text { the disinfection of prosthesis } \\
\text { sent/received to/in the } \\
\text { laboratory }\end{array}$} & Yes & $28.72 \%$ & $29.79 \%$ & $58.51 \%$ & \multirow{3}{*}{$\begin{array}{r}0.206 \\
(0.403)\end{array}$} \\
\hline & No & $22.34 \%$ & $19.15 \%$ & $41.49 \%$ & \\
\hline Total & & $51.06 \%$ & $48.94 \%$ & $100.0 \%$ & \\
\hline \multirow{6}{*}{$\begin{array}{l}\text { Products commonly used for } \\
\text { disinfection }\end{array}$} & Glutaraldehyde & $19.15 \%$ & $1.06 \%$ & $20.21 \%$ & \multirow{7}{*}{$\begin{array}{l}27.471^{* *} \\
(<0.001)\end{array}$} \\
\hline & lodophor & $5.32 \%$ & $8.51 \%$ & $13.83 \%$ & \\
\hline & $\begin{array}{l}\text { Quaternary } \\
\text { ammonium }\end{array}$ & $0.00 \%$ & $9.57 \%$ & $9.57 \%$ & \\
\hline & $\begin{array}{l}\text { Sodium } \\
\text { hypochlorite }\end{array}$ & $18.09 \%$ & $15.96 \%$ & $34.04 \%$ & \\
\hline & Phenolic & $0.00 \%$ & $2.13 \%$ & $2.13 \%$ & \\
\hline & None & $8.51 \%$ & $11.70 \%$ & $20.21 \%$ & \\
\hline Total & & $51.06 \%$ & $48.94 \%$ & $100.0 \%$ & \\
\hline
\end{tabular}

${ }^{*} \mathrm{P}<0.05$

${ }^{* *} P<0.001$ 


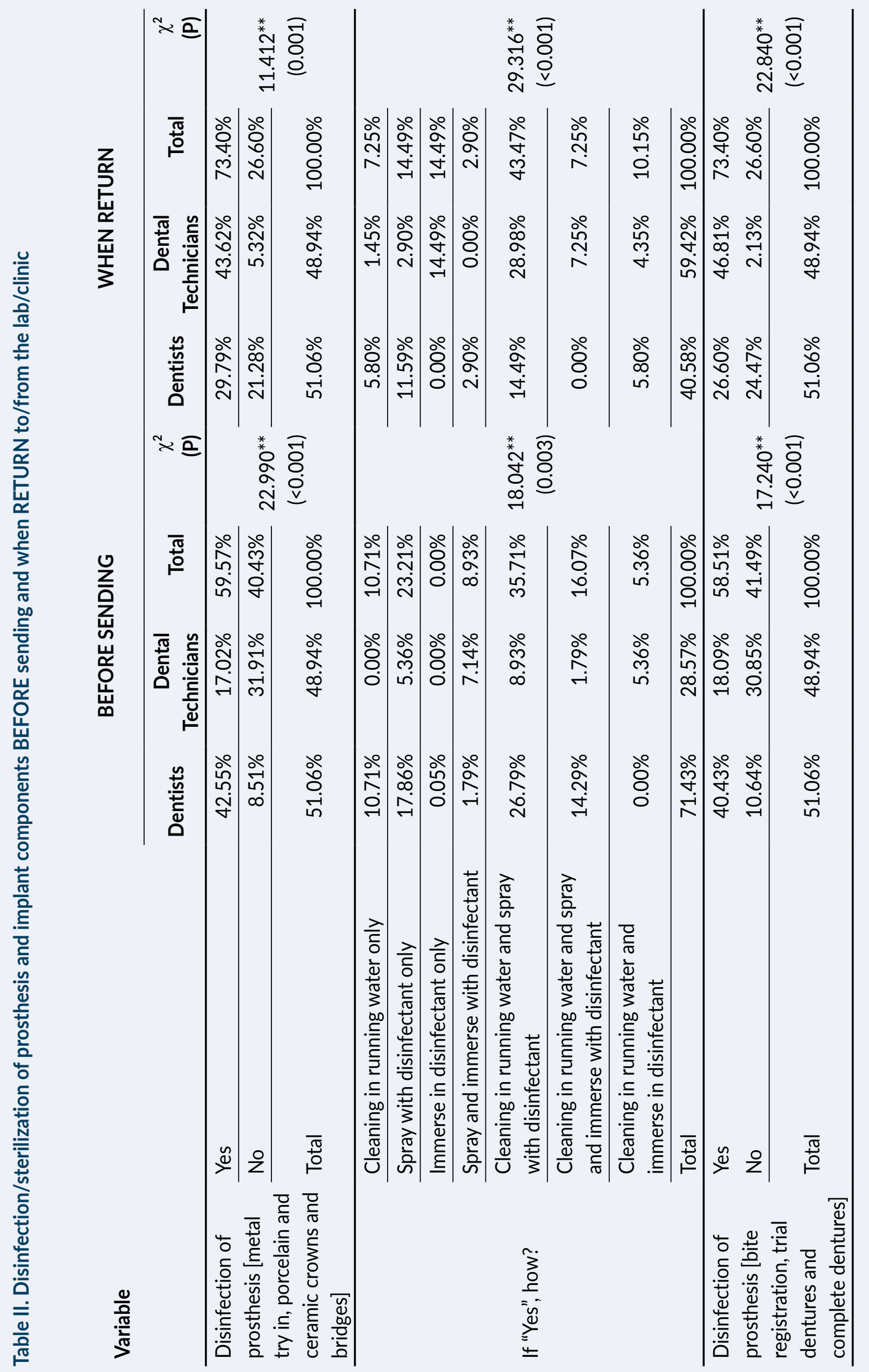




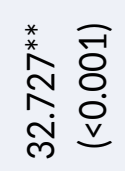

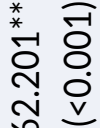

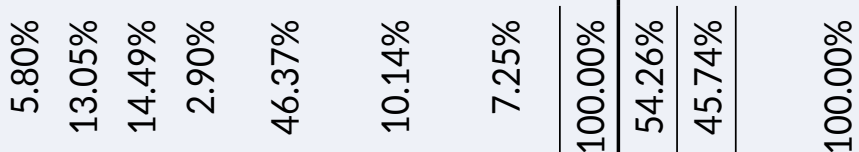

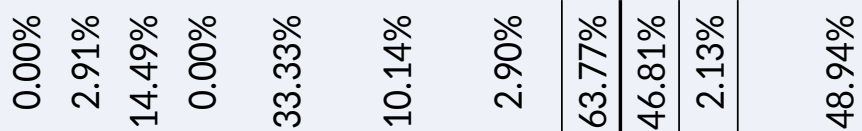

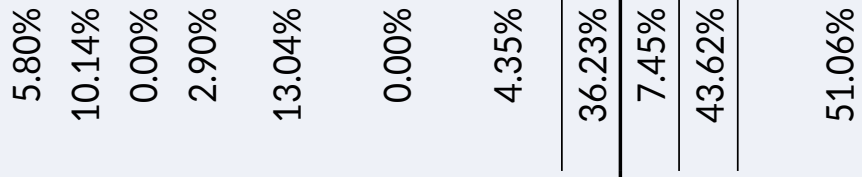

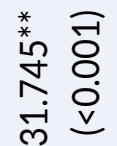

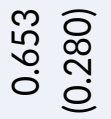

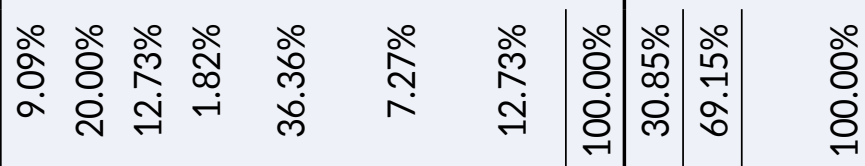

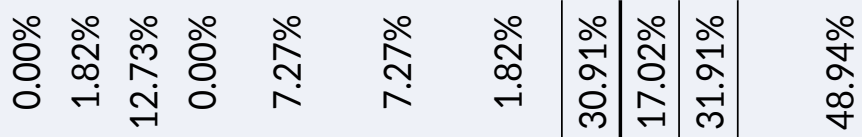

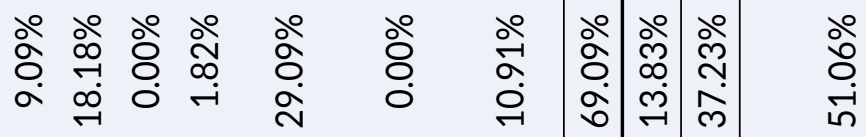

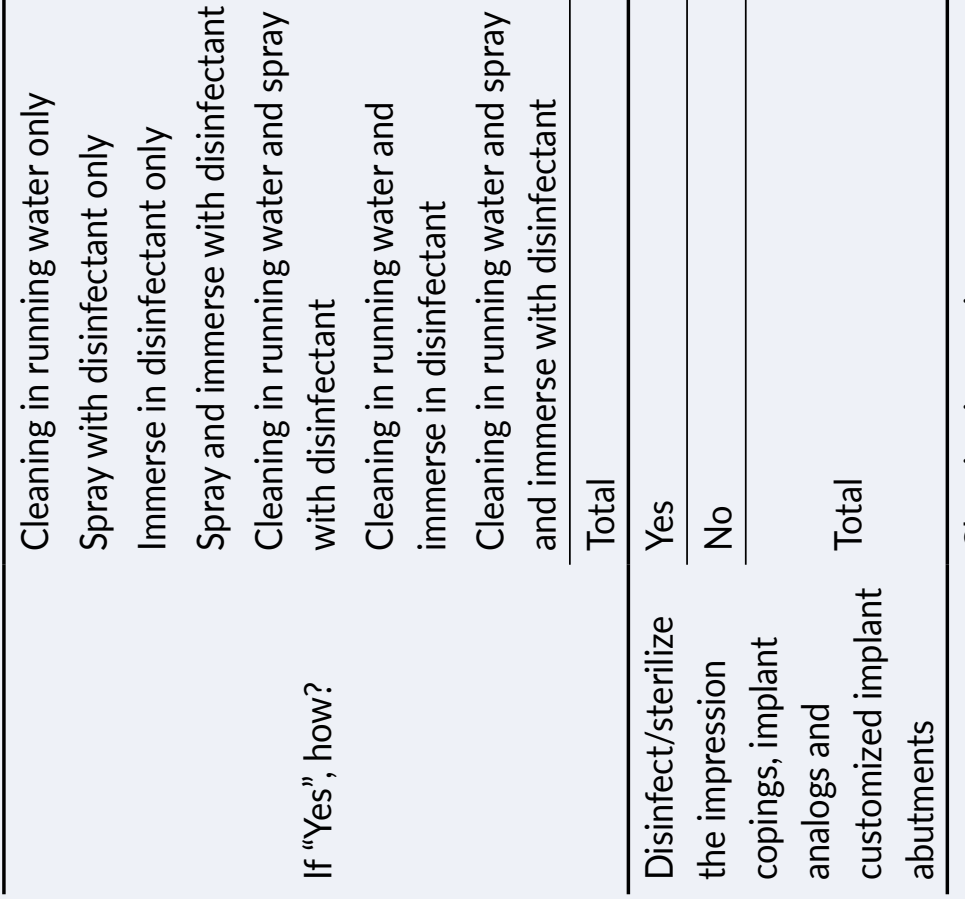

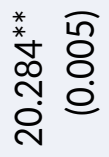

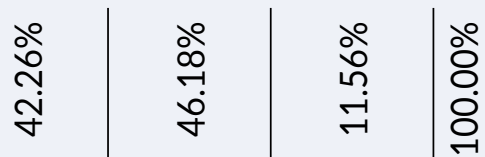

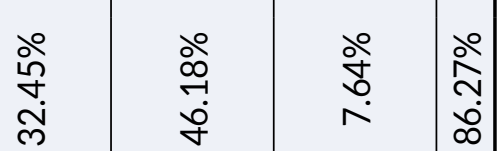

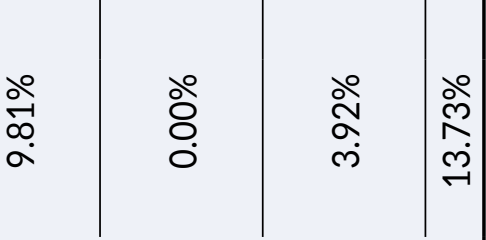

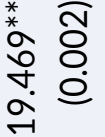

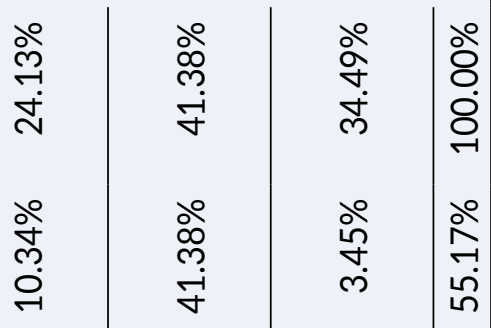

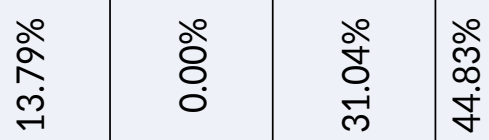

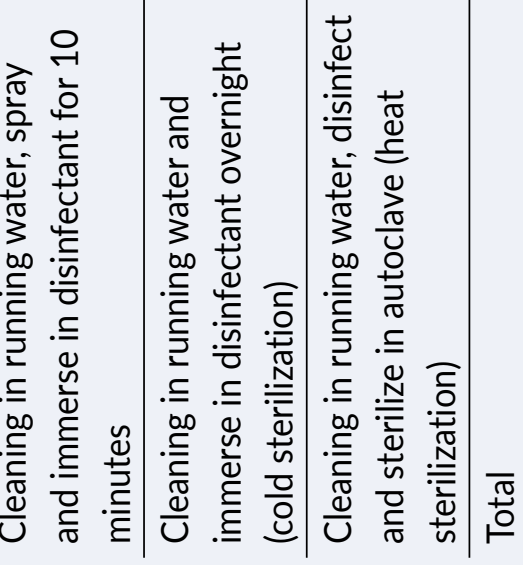

产 
On the other hand, asking about disinfection/ sterilization of prosthesis and implant components upon RETURN, a stastistically significant difference between dental technicians and dentists, as well as the methods used, was noted (Table II). There were also differences related to disinfection of bite registration, trial dentures and complete dentures, as well as the methods used for these (Table II). Finally, a statistically significant difference was noted between the studied groups related to disinfection/ sterilization of impression copings, implant analogs and customized implant abutments and the methods used for this (Table II).

Asking about the evaluation and satisfaction with performance of infection control measures in the prosthodontic clinic/lab, no statistical difference was recorded between the studied subjects concerning both the implementation of infection control measures and satisfaction with performance in infection control. Only $21.28 \%$ of the prosthodontists and $15.96 \%$ of the dental technicians evaluated their implementation of infection control measures as "good", while for satisfaction with performance in infection control $20.21 \%$ of the dentists were "almost satisfied" and $15.96 \%$ of the technicians were "fairly satisfied" (Table III).

Table IV shows the precautions taken by the dental technicians during trimming and when making metal framework castings for fixed and removable prostheses. $39.13 \%$ of the technicians apply all precautions during trimming and the $69.57 \%$ follow these precautions when making metal framework castings for fixed and removable prostheses.

Table $V$ depicts the effect of each independent variable in relation to application of infection control measures assessed by undergoing refresher courses of infection control, based on linear regression analysis. Out of the 17 variables studied, only two variables were statistically associated with the application of infection control measures. The first and best predictor variable was "the evaluation of implementation of

Table III. Evaluation and satisfaction with performance of infection control measures in the prosthodontic clinic/lab

\section{Group}

\begin{tabular}{|c|c|c|c|c|c|}
\hline \multirow{2}{*}{\multicolumn{2}{|c|}{ Variable }} & \multirow{3}{*}{$\begin{array}{l}\text { Dentists } \\
2.13 \% \\
\end{array}$} & \multirow{3}{*}{$\begin{array}{r}\begin{array}{r}\text { Dental } \\
\text { Technicians }\end{array} \\
3.19 \%\end{array}$} & \multirow[b]{2}{*}{ Total } & \multirow[b]{2}{*}{$\begin{array}{l}\chi^{2} \\
\text { (P) }\end{array}$} \\
\hline & & & & & \\
\hline \multirow{5}{*}{$\begin{array}{l}\text { Evaluation of implementation } \\
\text { of infection control in } \\
\text { prosthodontic clinic/ lab }\end{array}$} & Very poor & & & $5.32 \%$ & \multirow{6}{*}{$\begin{array}{r}7.441 \\
(0.114\end{array}$} \\
\hline & Poor & $4.26 \%$ & $9.57 \%$ & $13.83 \%$ & \\
\hline & Fair & $9.57 \%$ & $14.89 \%$ & $24.47 \%$ & \\
\hline & Good & $21.28 \%$ & $15.96 \%$ & $37.23 \%$ & \\
\hline & Very good & $13.83 \%$ & $5.32 \%$ & $19.15 \%$ & \\
\hline Total & & $51.06 \%$ & $48.94 \%$ & $100.0 \%$ & \\
\hline \multirow{5}{*}{$\begin{array}{l}\text { Satisfaction with } \\
\text { performance in infection } \\
\text { control measures }\end{array}$} & Not satisfied & $2.13 \%$ & $3.19 \%$ & $5.32 \%$ & \multirow{6}{*}{$\begin{array}{r}6.452 \\
(0.168)\end{array}$} \\
\hline & Little satisfied & $4.26 \%$ & $8.51 \%$ & $12.77 \%$ & \\
\hline & Fairly satisfied & $9.57 \%$ & $15.96 \%$ & $25.53 \%$ & \\
\hline & Almost satisfied & $20.21 \%$ & $13.83 \%$ & $34.04 \%$ & \\
\hline & Totally satisfied & $14.89 \%$ & $7.45 \%$ & $22.34 \%$ & \\
\hline \multicolumn{2}{|l|}{ Total } & $51.06 \%$ & $48.94 \%$ & $100.0 \%$ & \\
\hline
\end{tabular}


Table IV. Precautions taken by the technicians during trimming and when making metal framework castings for fixed and removable prostheses

Variable

Frequency

Percent

\begin{tabular}{|c|c|c|c|}
\hline \multirow{7}{*}{$\begin{array}{l}\text { Precautions taken during } \\
\text { trimming }\end{array}$} & clinic attire & 5 & 10.87 \\
\hline & protective eyewear & 2 & 4.35 \\
\hline & exam gloves & 4 & 8.70 \\
\hline & clinic attire and protective eyewear & 4 & 8.70 \\
\hline & clinic attire, mask and exam gloves & 13 & 28.26 \\
\hline & All Precautions & 18 & 39.13 \\
\hline & Total & 46 & 100.0 \\
\hline \multirow{6}{*}{$\begin{array}{l}\text { Precautions taken when } \\
\text { making metal framework } \\
\text { castings for fixed and } \\
\text { removable prostheses }\end{array}$} & clinic attire & 4 & 8.70 \\
\hline & protective eyewear & 3 & 6.52 \\
\hline & mask & 1 & 2.17 \\
\hline & clinic attire and protective eyewear & 6 & 13.04 \\
\hline & All Precautions & 32 & 69.57 \\
\hline & Total & 46 & 100.0 \\
\hline
\end{tabular}

Table V. Significant variables related to application of infection control measures assessed by undergoing refresher courses of infection control based on linear regression analysis

\begin{tabular}{|c|c|c|c|c|c|c|c|}
\hline \multirow[t]{2}{*}{ Model } & \multirow[t]{2}{*}{ Variables } & $\begin{array}{r}\text { Unstandardized } \\
\text { Coefficients }\end{array}$ & $\begin{array}{r}\text { Standardized } \\
\text { Coefficients }\end{array}$ & \multirow[t]{2}{*}{$\mathbf{R}^{2}$} & \multirow{2}{*}{$\begin{array}{r}\mathrm{R}^{2} \\
\text { Change }\end{array}$} & \multirow[t]{2}{*}{$t$} & \multirow[t]{2}{*}{ P-value } \\
\hline & & B & Beta & & & & \\
\hline \multirow[b]{2}{*}{1} & (Constant) & 2.484 & & \multirow[b]{2}{*}{0.622} & \multirow[b]{2}{*}{0.622} & 25.045 & $<0.001$ \\
\hline & $\begin{array}{l}\text { Evaluation of } \\
\text { implementation of } \\
\text { infection control } \\
\text { measures }\end{array}$ & -0.332 & -0.789 & & & -12.316 & $<0.001$ \\
\hline \multirow{3}{*}{2} & (Constant) & 2.328 & & \multirow{3}{*}{0.643} & \multirow{3}{*}{0.020} & 19.575 & $<0.001$ \\
\hline & $\begin{array}{l}\text { Evaluation of } \\
\text { implementation of } \\
\text { infection control } \\
\text { measures }\end{array}$ & -0.322 & -0.765 & & & -12.023 & $<0.001$ \\
\hline & $\begin{array}{l}\text { Products commonly } \\
\text { used for disinfection }\end{array}$ & 0.033 & 0.144 & & & 2.265 & 0.026 \\
\hline
\end{tabular}


infection control measures", where those subjects who received refresher courses of infection control during the previous year were 62.2 times considering the implementation of infection control procedures as "good" and "very good" than those who didn't attend those courses. Furthermore, "the products commonly used for disinfection" was the second predictor variable that was likely to affect the application of infection control measures in dental lab/clinic, where those subjects who received refresher courses evaluated the implementation of infection control processes as "good" and "very good" as well as being recognizable, experienced and dedicated to use the different types of commonly used disinfectants by two times more than the studied subjects who didn't get refresher courses of infection control in last year. Table VI shows the effect of each independent variable in relation to written infection control policy for incoming prostheses. Out of seventeen variables studied, only three variables were statistically associated with the application of infection control measures. The first and best predictor variable was "disinfect the prosthesis [metal try in, porcelain and ceramic crowns and bridges] BEFORE sending". The dentist/technician who had a written disinfection protocol for incoming prosthesis, disinfects prostheses 25.3 times more than those who didn't have a written policy. The second predictor variable was "disinfect the casts and the prosthesis of the complete dentures upon RETURN after jaw relations and wax trial". The subjects who do disinfect the metal try in, porcelain and ceramic crowns and bridges BEFORE sending to the lab/clinic, committed seven times more to do this for the casts and the prosthesis of the complete dentures upon RETURN after jaw relations and wax trial. The last predictor was "the products commonly used for disinfection"; those subjects who disinfect the prosthesis before sending as well as disinfect the casts and the prosthesis of the complete dentures upon RETURN are 4.2 times familiar, knowledgeable and committed to use the different types of commonly used disinfectants in the clinic/lab.

\section{Discussion}

Infection control is an essential part of practice for all healthcare providers and is considered as one of the most cost-beneficial available interventions. ${ }^{36}$ In prosthodontics, objects that are potentially contaminated with pathogenic microorganisms are transferred to and from the dental clinic and lab. While laboratory technicians do not have the initial responsibility in controlling cross-infection, they are in charge of applying the disinfection procedures of appliances received from and sent back to the dental office. $^{37}$

Efficient communication and coordination between the dental clinic and dental lab will guarantee that proper cleaning and disinfection procedures are implemented either in the dental clinic or lab so that disinfection is ensured, but duplication of procedures should be avoided. ${ }^{30}$ Findings of the current study revealed that communication between dentists and the dental technicians regarding the disinfection of prosthesis sent/received to/in the laboratory was poor as only $28.72 \%$ of the participating dentists and $29.79 \%$ of the technicians reported that they do communicate with each other for this item, meaning that there is deficiency in the communication between them. This is not in accord with the recommendations of Kohli and Puttaiah ${ }^{38}$ as they stated that adequate communications should be organized between the dental lab and the clinic concerning decontamination of the items that have been delivered. Also, these results are in contrast to that reported by Gupta et al. ${ }^{39}$ who found that $71.15 \%$ of the dental technicians communicate with the dentists. On the other hand, the current findings agreed with that of Al-Kheraif et al. ${ }^{40}$ who concluded that $90.6 \%$ of the laboratories did not have any communication with the clinics with regard to the disinfection procedures of prosthesis.

Infection control training courses are considered one of the main reasons for maintaining infection control practices in dental clinics and laboratories. In the current study $41.49 \%$ of the dentists had undergone refresher courses on infection control for the past year compared to only $26.60 \%$ of dental technicians. These results may explain the poor compliance of dental technicians to apply infection control measures with regard to prosthesis and implant components upon receiving these from the dental clinics, while the majority of them reported that they do comply with the infection control guidelines for the returned prosthesis as well as the impression copings, implant analogs and customized implant abutments to the 
Table VI. Significant variables related to application of infection control measures assessed by having written infection control policy for incoming prosthesis based on linear regression analysis

\begin{tabular}{|c|c|c|c|c|c|c|c|}
\hline \multirow[t]{2}{*}{ Model } & \multirow[t]{2}{*}{ Variables } & $\begin{array}{r}\text { Unstandardized } \\
\text { Coefficients }\end{array}$ & $\begin{array}{r}\text { Standardized } \\
\text { Coefficients }\end{array}$ & \multirow[t]{2}{*}{$\mathbf{R}^{2}$} & \multirow{2}{*}{$\begin{array}{r}R^{2} \\
\text { Change }\end{array}$} & \multirow[t]{2}{*}{$t$} & \multirow[t]{2}{*}{ P-value } \\
\hline & & B & Beta & & & & \\
\hline \multirow[b]{2}{*}{1} & (Constant) & 0.624 & & & & 5.690 & $<0.001$ \\
\hline & $\begin{array}{l}\text { Disinfect prosthesis } \\
\text { [metal try in, porcelain } \\
\text { and ceramic crowns } \\
\text { and bridges] BEFORE } \\
\text { sending }\end{array}$ & 0.412 & 0.503 & 0.253 & 0.253 & 5.583 & $<0.001$ \\
\hline \multirow{3}{*}{2} & (Constant) & 0.303 & & & & 2.042 & 0.044 \\
\hline & $\begin{array}{l}\text { Disinfect prosthesis } \\
\text { [metal try in, porcelain } \\
\text { and ceramic crowns } \\
\text { and bridges] BEFORE } \\
\text { sending }\end{array}$ & 0.423 & 0.517 & & & 5.990 & $<0.001$ \\
\hline & $\begin{array}{l}\text { Disinfect casts } \\
\text { and prosthesis of } \\
\text { complete dentures } \\
\text { when RETURN after } \\
\text { jaw relations and wax } \\
\text { trial }\end{array}$ & 0.241 & 0.265 & 0.323 & 0.070 & 3.064 & 0.003 \\
\hline \multirow{4}{*}{3} & (Constant) & 0.335 & & & & 2.310 & 0.023 \\
\hline & $\begin{array}{l}\text { Disinfect prosthesis } \\
\text { [metal try in, porcelain } \\
\text { and ceramic crowns } \\
\text { and bridges] BEFORE } \\
\text { sending }\end{array}$ & 0.313 & 0.382 & \multirow{3}{*}{0.365} & \multirow{3}{*}{0.042} & 3.793 & $<0.001$ \\
\hline & $\begin{array}{l}\text { Disinfect casts } \\
\text { and prosthesis of } \\
\text { complete dentures } \\
\text { when RETURN after } \\
\text { jaw relations and wax } \\
\text { trial }\end{array}$ & 0.197 & 0.217 & & & 2.513 & 0.014 \\
\hline & $\begin{array}{l}\text { Products commonly } \\
\text { used for disinfection }\end{array}$ & 0.049 & 0.249 & & & 2.440 & 0.017 \\
\hline
\end{tabular}


dental clinics. Prosthodontists revealed lack of commitment towards the disinfection/sterilization of the implant components in their clinics BEFORE sending to the lab as well as after RETURN, also this non-compliance was applied to disinfection of prosthesis upon RETURN from lab. These suggest that dental technicians and dentists are in urgent need of workshops and refresher training courses in measures of infection control so that they can practice these measures efficiently and continuously. Results of this study are somewhat better than that of Sammy et al., ${ }^{41}$ who found that $93.3 \%$ of the participating technicians had not undertaken any refresher infection control courses/training in the past year.

Forty three percent of the prosthodontists and $37.23 \%$ of the technicians confirmed that they have written disinfection protocols for incoming prosthesis. Results of the present study are somewhat lesser than what was registered by Jagger et al., ${ }^{42}$ who found that $49 \%$ of the dental laboratories in UK had a crossinfection policy. On the other hand, findings of this study are slightly higher than that of Gupta et al., ${ }^{39}$ who discovered that $25 \%$ of the dental technicians had infection control protocol and they were aware about it.

Khon et al., ${ }^{2}$ reported that proper disinfection for impressions, dental casts, denture prosthesis, cast metal framework, bite registration as well as wax rim, should be strictly performed before sending these items to the laboratory. Moreover, the guidelines of the CDC for infection control in dental health-care settings recommended specific strategies to control cross-contamination in the dental clinic and dental laboratory. ${ }^{43}$ In the present study, enquiry about the method of disinfection of interchanged prostheses between the clinic and lab revealed that cleaning in running water and spray with disinfectant was the most common method of disinfection applied by the dentists and the dental technicians to disinfect the different prostheses BEFORE sending to and after RETURN from the lab/clinic. Whereas, $12.73 \%$ of the technicians reported that they immerse bite registration, trial dentures and complete dentures in disinfectant only BEFORE sending to the clinic. Regarding the disinfectants used, glutaraldehyde and sodium hypochlorite (19.15\% and $18.09 \%$, respectively) were the most commonly used disinfectants by dentists, while $15.96 \%$ of the technicians reported that they used sodium hypochlorite as a disinfectant material and $11.70 \%$ of them didn't use any disinfectants. However, regarding the method of disinfection of different types of prostheses and the most commonly used disinfectant materials, findings of the current study are in agreement with that of previous studies. ${ }^{4-49}$

Aldosari concluded that sterilizing the implant components did not affect the accuracy of the impressions. ${ }^{50}$ This outcome denotes that impression copings and implant analogs can be safely sterilized without affecting the quality of the impressions made. On the other hand, Alikhasi et al., ${ }^{51}$ stated that it is better not to reuse the implant analogs as their removal from dental casts may lead to their distortion which could affect the transfer accuracy, while impression copings can be successfully used without compromising the impression accuracy after being cleaned and sterilized up to 10 times. Additionally, Shafie declared that implant abutments should be cleaned, disinfected, and, in particular clinical cases and procedures, be sterilized, following carefully all procedural instructions to avoid any accountability..$^{52}$ Questioning about disinfection/sterilization of the implant components BEFORE sending to the lab, the majority of prosthodontists and dental technicians in our study did not perform disinfection/sterilization for the impression copings, implant analogs and customized implant abutments (Table II). Further, while $46.81 \%$ of the technicians reported that they disinfect/sterilize these items after RETURN from the clinic, the majority of dentists did not, indicating inadequacy in the performance of infection control measures with regard to implant components.

In the current study, a minority of the dentists evaluated their implementation of infection control in the prosthodontic clinics as being "good" and "very good", and $20.21 \%$ of them were "almost satisfied" with their performance in infection control in their prosthodontic clinics (Table III). Also a small percentage of the dental technicians stated that they are "fair" and "good" at implementing infection control measures in their laboratories, with "fair satisfaction" about their performance in infection control measures (Table 
III). Only $39.13 \%$ of technicians apply all personal protective equipment as protective precautions during trimming.

These results reflect the perception of the participants concerning the implementation of infection control measures in the prosthodontic clinic/lab, and indicate the need for additional educational efforts to intensify the efforts to enhance their awareness and attitudes towards the application of infection control in their clinics/labs.

\section{Conclusion}

There is a lack of proper application of infection control measures in prosthodontic clinics and labs with regard to the disinfection of dental prostheses and the disinfection/sterilization of implant components upon sent/returned to the dental lab/clinic. As the study has been performed with dentists and dental technicians in only three cities of Qassim province in Saudi Arabia, and as the sample size is considered small in relation to the whole number of dentists and dental technicians belonging to $\mathrm{MoH}$ which are limitations in the current study, further studies are recommended to be directed to the prosthodontists and dental technicians in other areas of Saudi Arabia to offer a wider picture about the compliance and commitment of the target group with the recommended infection control programs.

\section{References}

1. Al-Dwairi ZN. Infection control procedures in commercial dental laboratories in Jordan. Journal of dental education 2007; 71(9): 1223-1227.

2. Kohn WG, Harte JA, Malvitz DM, Collins AS, Cleveland JL, Eklund KJ. Guidelines for infection control in dental health care settings--2003. J Am Dent Assoc 2004; 135(1): 33-47. https://doi.org/10.14219/jada.archive.2004.0019

3. Abreu MH, Lopes-Terra MC, Braz LF, Rimulo AL, Paiva SM, Pordeus IA. Attitudes and behavior of dental students concerning infection control rules: a study with a 10-year interval. Brazilian dental journal 2009; 20(3): 221-225. https:// doi.org/10.1590/S0103-64402009000300009

4. Taiwo JO, Aderinokun GA. Assessing cross infection prevention measures at the Dental Clinic, University College Hospital, Ibadan. African journal of medicine and medical sciences 2002; 31(3): 213-217.

5. Wakefield CW. Laboratory contamination of dental prostheses. The Journal of prosthetic dentistry 1980; 44(2): 143-146. https://doi.org/10.1016/0022-3913(80)90125-0
6. Connor C. Cross-contamination control in prosthodontic practice. The International journal of prosthodontics 1991; 4(4): 337-344.

7. Bhat VS, Shetty MS, Shenoy KK. Infection control in the prosthodontic laboratory. J Indian Prosthodont Soc 2007; 7: 62-65. https://doi.org/10.4103/0972-4052.33997

8. Matalon S, Eini A, Gorfil C, Ben-Amar A, Slutzky H. Do dental impression materials play a role in cross contamination? Quintessence Int 2011; 42(10): e124-e130.

9. Kohn WG, Collins AS, Cleveland JL, Harte JA, Eklund KJ, Malvitz DM. Guidelines for infection control in dental healthcare settings--2003. MMWR Recommendations and reports: Morbidity and mortality weekly report Recommendations and reports 2003; 52(RR-17): 1-61. https://doi.org/10.14219/ jada.archive.2004.0019

10. WHO. Practical Guidelines for Infection Control in Health Care Facilities. South-East Asian Regional Organisation Regional Publication No 41 2004; www.searo.who.int/LinkFiles/ Publications._PracticalguidelinSEAROpub-41.pdf.

11. Hatzikyriakos A, Petridis HP, Tsiggos N, Sakelariou S. Considerations for services from dental technicians in fabrication of fixed prostheses: A survey of commercial dental laboratories in Thessaloniki, Greece. The Journal of prosthetic dentistry 2006; 96(5): 362-366. https://doi.org/10.1016/j. prosdent.2006.08.017

12. Service $A B$. The control of cross infection in dentistry. Advice sheet A12. 1991.

13. Abdelaziz KM, Combe EC, Hodges JS. The effect of disinfectants on the properties of dental gypsum: 1 . Mechanical properties. Journal of prosthodontics: official journal of the American College of Prosthodontists 2002; 11(3): 161-167. https://doi.org/10.1053/jopr.2002.126860

14. Sofou A, Larsen T, Owall B, Fiehn NE. In vitro study of transmission of bacteria from contaminated metal models to stone models via impressions. Clinical oral investigations 2002; 6(3): 166-170. https://doi.org/10.1007/s00784-002-0174-3

15. Leung RL, Schonfeld SE. Gypsum casts as a potential source of microbial cross-contamination. The Journal of prosthetic dentistry 1983; 49(2): 210-211. https://doi. org/10.1016/0022-3913(83)90503-6

16. DePaola LG, Minah GE, Elias SA. Growth and potential pathogens in denture-soaking solution of myelosuppressed cancer patients. The Journal of prosthetic dentistry 1984; 51(4): 554-558. https://doi.org/10.1016/0022-3913(84)90313-5

17. Donovan T, Chee WW. Preliminary investigation of a disinfected gypsum die stone. The International journal of prosthodontics 1989; 2(3): 245-248.

18. Stern MA, Johnson GH, Toolson LB. An evaluation of dental stones after repeated exposure to spray disinfectants. Part I: Abrasion and compressive strength. The Journal of prosthetic dentistry 1991; 65(5): 713-718. https://doi. org/10.1016/0022-3913(91)90211-E

19. Bass RA, Plummer KD, Anderson EF. The effect of a surface disinfectant on a dental cast. The Journal of prosthetic dentistry 1992; 67(5): 723-725. https://doi.org/10.1016/00223913(92)90179-E 
20. Ivanovski S, Savage NW, Brockhurst PJ, Bird PS. Disinfection of dental stone casts: antimicrobial effects and physical property alterations. Dental materials: official publication of the Academy of Dental Materials 1995; 11(1): 19-23. https:// doi.org/10.1016/0109-5641(95)80004-2

21. Infection control recommendations for the dental office and the dental laboratory. ADA Council on Scientific Affairs and ADA Council on Dental Practice. J Am Dent Assoc 1996; 127(5): 672-680. https://doi.org/10.14219/jada. archive.1996.0280

22. Twomey JO, Abdelaziz KM, Combe EC, Anderson DL. Calcium hypochlorite as a disinfecting additive for dental stone. The Journal of prosthetic dentistry 2003; 90(3): 282-288. https:// doi.org/10.1016/S0022-3913(03)00412-8

23. Jansen VK, Conrads G, Richter EJ. Microbial leakage and marginal fit of the implant-abutment interface. The International journal of oral \& maxillofacial implants 1997; 12(4): 527-540.

24. International Organization forStandardization. EU/ISO17664: Sterilization of medical devices-Information to be provided by the manufacturer for resterilizable medical devices. http:// wwwisoorg/iso/catalogue_detailhtm?csnumber $=31456$. 2004.

25. Cleveland JL, Bonito AJ, Corley TJ, et al. Advancing infection control in dental care settings: factors associated with dentists' implementation of guidelines from the Centers for Disease Control and Prevention. J Am Dent Assoc 2012; 143(10): 1127-1138. https://doi.org/10.14219/jada. archive.2012.0044

26. Doundoulakis JH. Surface analysis of titanium after sterilization: role in implant-tissue interface and bioadhesion. The Journal of prosthetic dentistry 1987; 58(4): 471-478. https://doi.org/10.1016/0022-3913(87)90279-4

27. Kim JW, Covel NS, Guess PC, Rekow ED, Zhang Y. Concerns of hydrothermal degradation in CAD/CAM zirconia. Journal of dental research 2010; 89(1): 91-95. https://doi. org/10.1177/0022034509354193

28. Park JH, Olivares-Navarrete R, Baier RE, et al. Effect of cleaning and sterilization on titanium implant surface properties and cellular response. Acta biomaterialia 2012; 8(5): 1966-1975. https://doi.org/10.1016/j.actbio.2011.11.026

29. Li KC, Waddell JN, Prior DJ, et al. Effect of autoclave induced low-temperature degradation on the adhesion energy between yttria-stabilized zirconia veneered with porcelain. Dental materials: official publication of the Academy of Dental Materials 2013; 29(11): e263-e270. https://doi. org/10.1016/j.dental.2013.08.204

30. Lepe X, Johnson GH, Berg JC. Surface characteristics of polyether and addition silicone impression materials after long-term disinfection. The Journal of prosthetic dentistry 1995; 74(2): 181-186. https://doi.org/10.1016/S00223913(05)80184-2

31. Scully C, Greenspan JS. Human immunodeficiency virus (HIV) transmission in dentistry. Journal of dental research 2006; 85(9): 794-800. https://doi.org/10.1177/154405910608500903

32. de Souza RA, Namen FM, Galan J Jr, Vieira C, Sedano HO. Infection control measures among senior dental students in Rio de Janeiro State, Brazil. Journal of public health dentistry 2006; 66(4): 282-284. https://doi.org/10.1111/j.1752-7325.2006. tb04084.x
33. Acosta-Gio AE, Borges-Yanez SA, Flores M, et al. Infection control attitudes and perceptions among dental students in Latin America: implications for dental education. International dental journal 2008; 58(4): 187-193. https://doi.org/10.1111/ j.1875-595X.2008.tb00347.x

34. Singh A, Purohit BM, Bhambal A, Saxena S, Gupta A. Knowledge, attitudes, and practice regarding infection control measures among dental students in Central India. Journal of dental education 2011; 75(3): 421-427.

35. KSA. Annual Statistical Book 2017. https://www.moh.gov. sa/Ministry/Statistics/book/Documents/\%D8\%A7\%D9\%8 4\%D9\%83\%D8\%AA\%D8\%A7\%D8\%A8\%20\%D8\%A7\%D9 \%84\%D8\%A5\%D8\%AD\%D8\%B5\%D8\%A7\%D8\%A6\%D9\% 8A\%201438.pdf

36. Wenzel RP. The Lowbury Lecture. The economics of nosocomial infections. The Journal of hospital infection 1995; 31(2): 79-87. https://doi.org/10.1016/01956701(95)90162-0

37. Campanha NH, Pavarina AC, Vergani CE, Machado AL, Giampaolo ET. Cross-Infection Control Policy Adopted by Dental Technicians. Revista de Odontologia da UNESP 2004; 33(4): 195-201.

38. Kohli A, Puttaiah R. Infection Control \& Occupational Safety Recommendations for Oral Health Professionals. 1st ed New Delhi: Dental Council of India 2007; 2: 14.

39. Gupta S, Rani S, Garg S. Infection control knowledge and practice: A cross-sectional survey on dental laboratories in dental institutes of North India. J Indian Prosthodont Soc 2017; 17(4): 348-354. https://doi.org/10.4103/jips.jips_5_17

40. Al-Kheraif AA, Mobarak FA. Infection control practice in private dental laboratories in Riyadh. Saudi Dental Journal 2008; 20(3): 163-169

41. Sammy KC, Benjamin SN. Infection control mechanisms employed by dental laboratories to prevent infection of their dental technicians/technologists. J Oral Health Craniofac Sci 2016; 1: 1-11. https://doi.org/10.29328/journal. johcs.1001001

42. Jagger DC, Huggett R, Harrison A. Cross-infection control in dental laboratories. British dental journal 1995; 179(3): 93-96. https://doi.org/10.1038/sj.bdj.4808846

43. Centers for Disease Control and Prevention. 2003 CDC infection control recommendations for dental health-care settings. Compend Contin Educ Dent 2004; 25(1 Suppl): 43$48,50-53$

44. McGowan MJ, Shimoda LM, Woolsey GD. Effects of sodium hypochlorite on denture base metals during immersion for short-term sterilization. J Prosthet Dent 1988; 60: 212-218. https://doi.org/10.1016/0022-3913(88)90318-6

45. Bell JA, Brockmann SL, Feil P, Sackuvich DA. The effectiveness of two disinfectants on denture base acrylic resin with an organic load. The Journal of prosthetic dentistry 1989; 61(5): 580-583. https://doi.org/10.1016/0022-3913(89)90280-1

46. Shen C, Javid NS, Colaizzi FA. The effect of glutaraldehyde base disinfectants on denture base resins. The Journal of prosthetic dentistry 1989; 61(5): 583-589. https://doi. org/10.1016/0022-3913(89)90281-3 
47. David GD, Glen HJ, Powell GL. The accuracy and efficacy of disinfection by spray atomization impression. J Prosthet Dent 1989; 62: 468-75. https://doi.org/10.1016/00223913(89)90183-2

48. Brace ML, Plummer KD. Practical denture disinfection. The Journal of prosthetic dentistry 1993; 70(6): 538-540. https:// doi.org/10.1016/0022-3913(93)90268-S

49. Gregory L, Alkibiades JZ, Stavros AY. The effect of glutaraldehyde and microwave disinfection on some properties of acrylic denture resin. Tnt J Prosthodont 1995; 8: 150-154.

50. Aldosari AMA. Does steam autoclaving affect the accuracy of implant impression systems? Journal of Biomaterials and Tissue Engineering 2014; 4: 550-554. https://doi.org/10.1166/ jbt.2014.1207
51. Alikhasi M, Bassir SH, Naini RB. Effect of multiple use of impression copings on the accuracy of implant transfer. The International journal of oral \& maxillofacial implants 2013; 28(2): 408-414. https://doi.org/10.11607/jomi.2717

52. Shafie HR. Clinical and laboratory manual of dental implant abutments. First Edition Edited by Hamid R Shafie John Wiley \& Sons, Inc Published 2014 by John Wiley \& Sons, Inc. 2014. https://doi.org/10.1002/9781118928547 